\title{
DEVELOPMENT OF AN APPROACH TO DETERMINING THE LEVEL OF CAPITALIZATION OF CORPORATE ENTERPRISES ON THE BASIS OF THE EVALUATION MECHANISM
}

\author{
Liudmyla Zaitseva' ${ }^{1}, K$ seniia Sieriebriak ${ }^{2}$
}

\begin{abstract}
The purpose of the article is to substantiate the approach to determining the level of capitalization of corporate enterprises on the basis of the evaluation mechanism. In accordance with the set goal the following tasks were solved: to evaluate the possibility of applying the existing approaches to the capitalization assessment, to substantiate the approach to the capitalization assessment of the enterprise taking into account the factors of assessment quality, and to determine the ways of increasing the capitalization of corporate enterprises. Methodology. The methodological component of the study is the cost approach to assessing the capitalization of an enterprise. The proposed approach is based on the integration of private assessments of the enterprise value, including the use of financial statements, which makes it possible to identify areas to increase the level of capitalization at the expense of the enterprise's own efficiency. The method of dialectical approach in understanding the economic essence of enterprise capitalization through its general and specific functions, determining the directions of efficiency and tools to increase the capitalization of the enterprise. The results of assessing the level of corporate companies' capitalization serve as an information base for making managerial decisions on the choice of sources of increasing the market value in the future. Practical implications. The study used the method of comparison and generalization in assessing the level of capitalization of the enterprise. The information base of the study are scientific developments of Ukrainian and foreign authors on the assessment of the level of capitalization of the enterprise, the materials of Ukrainian stock exchanges and official publications of financial statements of PJSC "Ukrnafta", PJSC "Turboatom". Value/ originality. The proposed capitalization assessment model takes into account the factors of quality assessment and makes it possible to form an information platform for investors on forecasts of return on invested capital and risk on their shares.
\end{abstract}

Key words: capitalization, market value, cost approach, corporate enterprises, enterprise value, valuation quality.

JEL Classification: G12, G31, E22

\section{Introduction}

The process of globalization, characteristic of modern business, has determined the orientation of companies on the principles of sustainable development. Currently, more and more Ukrainian companies are moving towards the development of corporate transparency, social responsibility and environmental efficiency. The trends mentioned allow business entities to implement rational consumption and production models in order to effectively manage material risks and costs, facilitate access to new markets by strengthening competitiveness and improve reputation, relationships with stakeholders and investment attractiveness, which results in increasing companies' capitalization.

Capitalization is a reflection of the market value of shares and an integral assessment of the company's stability, profitability and competitiveness. The capitalization process is a diverse and dynamic phenomenon, the result of purposeful creation and management of companies' value. In the system of strategic and financial goals of enterprise development, preference is given to the growth of market capitalization as a key indicator of investment attractiveness by increasing the value of enterprises. The importance

\footnotetext{
Corresponding author:

${ }^{1}$ State Institution "Luhansk Taras Shevchenko National University", Ukraine.

E-mail: mila280176@ukr.net

ORCID: https://orcid.org/0000-0002-9388-5500

${ }^{2}$ Volodymyr Dahl East Ukrainian National University, Ukraine.

E-mail: serebriakki@ukr.net

ORCID: https://orcid.org/0000-0002-7025-2399
} 
of this research direction is confirmed by the need to select the sources of capitalization and the factors that affect it. With the current state of the economy in Ukraine and other countries where the financial market is in its infancy, the issue of assessing the level of capitalization becomes particularly relevant. There is a need for information on the future development of the company, which is used to monitor and analyze the expectations of investors and stakeholders in the value creation processes. However, the formation of a comprehensive system of capitalization assessment based on the cost approach and the identification of factors affecting the quality of assessment require further justification and development.

The study is devoted to substantiation of theoretical provisions and development of recommendations for determining the level of companies' capitalization on the basis of the evaluation mechanism. The new model of capitalization valuation is based on the cost approach and the integration of private valuations of the enterprise by the methods of expenses, income and market methods, taking into account the quality factor of valuation.

The practice of using the evaluation mechanism was demonstrated on the example of the activities of PJSC "Ukrnafta" and PJSC "Turboatom". The financial records of the companies for 2016-2020 were used as initial data.

\section{Analysis of the current state of the level of enterprises' market capitalization with the help of the exchange mechanism}

The analysis of modern scientific sources devoted to the problems of capitalization assessment allows us to form certain generalizations about the essence of capitalization, approaches and methods of enterprise capitalization assessment.

Works of many scientists are devoted to the study of capitalization as an economic category, as well as the classification of criteria and approaches to the assessment of the value and capitalization of the enterprise, but the uncertainty increases the relevance of this definition.

The economic literature presents such directions of understanding of "capitalization": the process of transforming resources into value, which brings additional value (Gritsenko, 2009), (Mocherny, 2000), (Buleev \& Bryukhovetskaya, 2011); the process of transformation of income into the total capital of the enterprise (Rosenberg, 1997), (Kozoriz, 2007), (Davydenko, 2016); category of financial management (Blank, 2004), (Melnyk, 2009); basic indicator for assessing the value of the enterprise in the stock market (Shevchenko, 2008), (Pronko, Kolesnik \& Samborskaya, 2021).
In modern economic development the importance of the process of corporate enterprises capitalization is increasing, the task of which is to provide a return on invested capital in the form of an increase in the market value of shares on the stock market by improving their efficiency, the quality of corporate governance, openness and transparency. Based on the strategic goal of the company, i.e., the growth of its market value, the study and analysis of changes in market capitalization is a priority.

Capitalization is manifested through its functions: general (evaluation, forecasting, strategic, informational, social, stimulating, innovative, investment) and specific (personal for each species, for real - mobilization, reproduction, distribution, for marketing - image, protective, identification; for market - commercial, generating, integration), emphasizing the functional features of the above types (Pronko, Kolesnik \& Samborskaya, 2021), (Kryvovyazyuk, Pushkarchuk \& Volynchuk, 2017), (Lishchikova, Nikulina, Orlova \& Chistnikova, 2015).

Particular attention needs to be paid to assessing the level of market capitalization, which is manifested through the exchange mechanism. Market capitalization means the market value of all shares of an enterprise. That is, the market capitalization of enterprises is inextricably linked to the level of development of the stock market, changes in regulation and the efficiency of issuers. However, the growth of corporate capitalization in Ukraine is constrained by the low level of stock market development, high risk of capital accumulation and its use. The Ukrainian stock market is insufficiently connected with the real processes in the economy, as evidenced by the dynamics of GDP and the volume of trade in shares during 2010-2019 in Ukraine (Figure 1).

The vast majority of Ukrainian issuers have a low percentage of free float shares. The level of free float is shown on the example of companies that make up the index basket of the Ukrainian Stock Exchange (Table 1).

Table 1

Level of free float companies of the index basket of the Ukrainian Stock Exchange as of February 2021

\begin{tabular}{|c|l|c|c|}
\hline Ticker UX & \multicolumn{1}{|c|}{$\begin{array}{c}\text { Enterprise, } \\
\text { PJSC }\end{array}$} & $\begin{array}{c}\text { Index weight, } \\
\%\end{array}$ & $\begin{array}{c}\text { Free-float, } \\
\%\end{array}$ \\
\hline BAVL & Raiffeisen Bank Aval & 20,16 & 2,0 \\
\hline CEEN & Centerenergo & 24,43 & 22,0 \\
\hline DOEN & Donbasenergo & 2,37 & 14,0 \\
\hline MSICH & Motor Sich & 20,82 & 20,5 \\
\hline TATM & Turboatom & 4,29 & 3,5 \\
\hline UNAF & Ukrnafta & 27,93 & 7,0 \\
\hline
\end{tabular}

Thus, the level of free float of 2 out of 6 index participants is less than 5\%, which indicates a tendency towards price speculation and low liquidity of corporate securities, a low level of free float. 


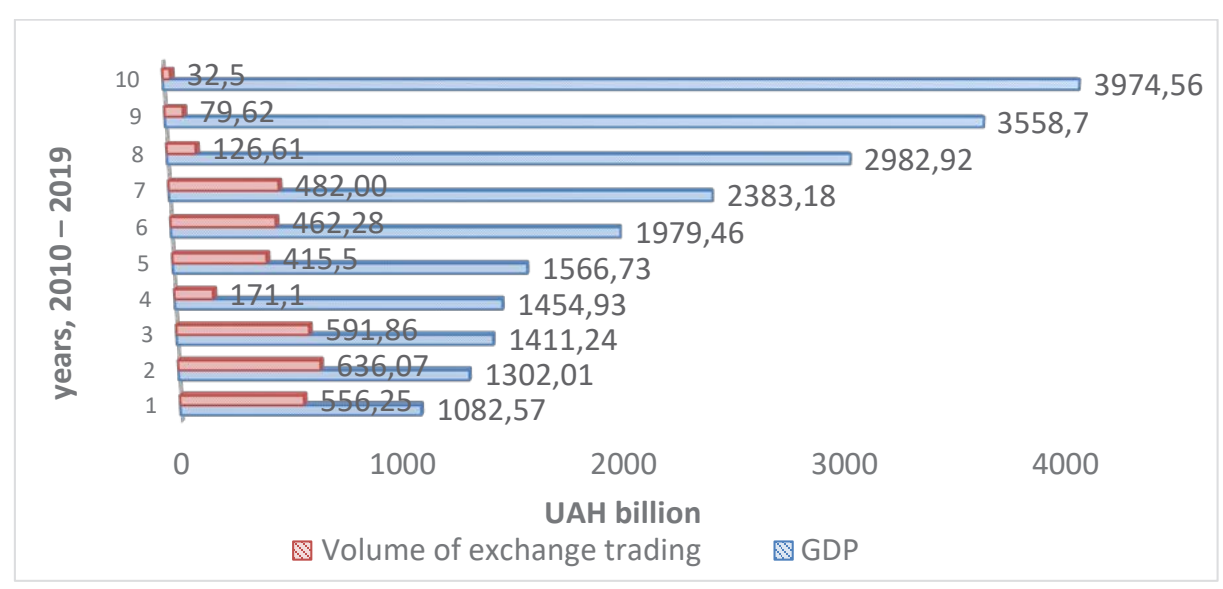

Figure 1. Comparative dynamics of trading volume of issuers' shares and level of GDP in Ukraine in 2010-2019 in billion UAH

The data from the analysis of the index basket of the Ukrainian Stock Exchange indicate the high cost of attracting funds through the issue of shares and the lack of economic incentives to increase free float by Ukrainian companies. The costs associated with servicing a stock offering are higher than the costs of debt, even allowing for the possibility of offering shares at a higher price during periods of favorable market conditions (Zaitseva, 2021).

In Ukraine there is practically no real attraction of capital through shares on the stock market, it is cheaper and easier for issuers to raise funds on foreign markets, through bonds, loans, direct investments, etc. Attracting capital through shares is almost exclusively an over-the-counter method, in Ukraine not a single IPO was carried out. The stock market in Ukraine was virtually destroyed, the volume of exchange trading in 2019 was only 32 billion UAH ( 17 times less than in 2010, (Figure 1)).

The liquidity of the stock market in Ukraine is negatively affected by the unfavorable investment climate, as well as the lack of proper investor confidence. However, the reforms in Ukraine in
2014-2020 restored investor confidence. The volume of trades on stock exchanges as of the end of 2014 amounted to UAH 816834 million, including: for shares - UAH 34516.5 million, and at the end of 2019 the volume of trades on stock exchanges decreased to UAH 277034 million, including: for shares - up to UAH 332 million, ie by $99.3 \%$.

The limited nature of the domestic stock market (Figure 2) and low efficiency of issuers reduce the role of the market value of shares as an indicator of the companies' capitalization. The efficiency of an enterprise indirectly affects the level of market capitalization. This is confirmed by the high dynamics of the market capitalization of enterprises, which does not allow an objective assessment of its level.

\section{Comprehensive approach to assessing the capitalization of enterprises}

Capitalization, as a process, is related to the various mechanisms and methods of moving the value of an enterprise, which are evaluated through its internal potential and the value of its shares. In modern practice, to

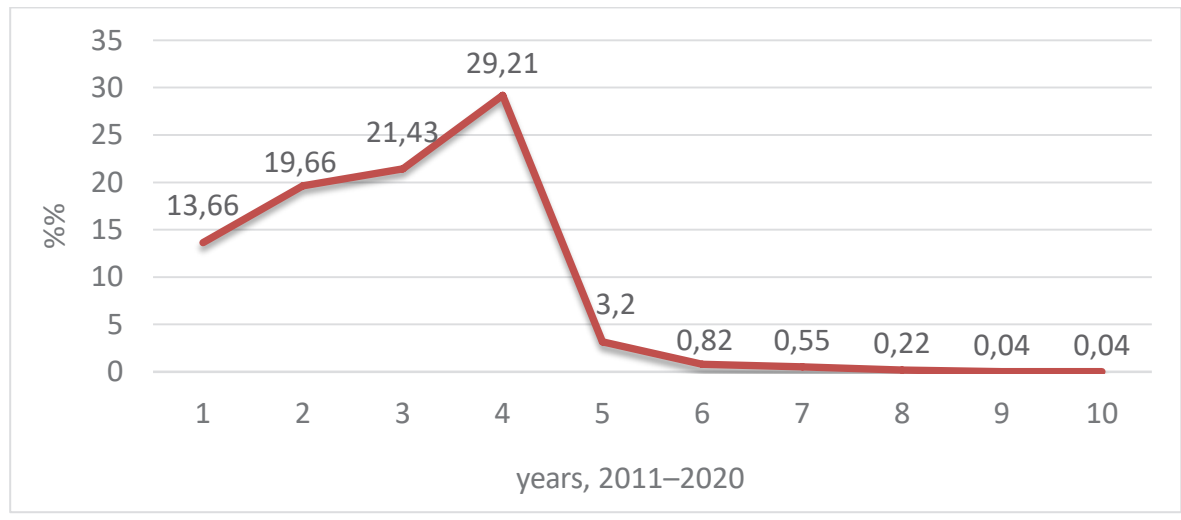

Figure 2. Dynamics of capitalization level of listed companies as \% of GDP of Ukraine from 2011 to 2020 
determine the size of the capitalization of the enterprise there used exchange, over-the-counter, evaluation and research mechanisms. The exchange mechanism is based on the actions of speculators in buying and selling shares traded on the exchange. The OTC mechanism is based on agreements on the purchase and sale of shares of the company, which are not traded on the stock market and have no liquidity. Evaluation and research mechanisms calculate the potential value of the company's capitalization, which can be realized in the case of a purchase and sale transactions of the company or its share (Sabadireva, 2017).

Actual problem of capitalization level assessment is the justification of cost approach, which allows to estimate the level of capitalization of enterprise in the context of the target vector of management, taking into account the development of the Ukrainian stock market and performance parameters of corporate enterprises.

The valuation mechanism of capitalization of corporate enterprises is considered through the integrated use of the following methods: cost (property) (value of assets and liabilities) (Balitska \& Pyskun, 2020), profitable (by analogy) and market (in terms of future income), which are based on factors that generate added value. The practice of using the evaluation mechanism is demonstrated by the example of PJSC Ukrnafta and PJSC Turboatom (Figure 3).

The graphical interpretation of the results of capitalization level assessment (Figure 1) shows the greatest discrepancy between the indicators calculated by different approaches, in particular, the capitalization assessment by the market approach is overestimated. This is due to the following:

- the capitalization ratio of the cost approach is static and characterizes the past value, does not take into account the market situation at the valuation date and has no relationship with the activity results. In essence, it determines the availability of investment resources of the enterprise, i.e., the minimum level of capitalization. Under this approach, the capitalization of an enterprise is calculated as the sum of the values of all assets minus the value of liabilities. Accounting data and financial statements are the main source of information. The use of the cost method is justified if the book and market value of assets do not differ significantly. However, the book value of assets often does not correspond to their market value. Therefore, the calculated cost of the enterprise should be adjusted for the cost of goodwill; - the capitalization ratio according to the profit approach is a dynamic value that characterizes the value of future cash flows and takes into account the time horizon, the discount rate and varies depending on the results of the enterprise. However, it does not take into account market conditions;

- market capitalization ratio is calculated on the basis of real market data and takes into account the influence of industry factors on stock prices, risk adjustments, comparisons with similar companies, but it is acceptable in a developed stock market. It should be borne in mind that to assess the capitalization, the discount rate is taken in the amount of the cost of raising equity: (expected by investors rate of return), as a result, for the same company discount rates may be different.

Analysis of the strength of the correlation between the quantitative values of the level of capitalization of PJSC "Ukrnafta" on the cost and profit approach $(\mathrm{r}=-0.45)$, and the profit and market approach $(r=-0.27)$ indicate a negative relations, the relations between cost and market $(r=-0.63)$ demonstrates the

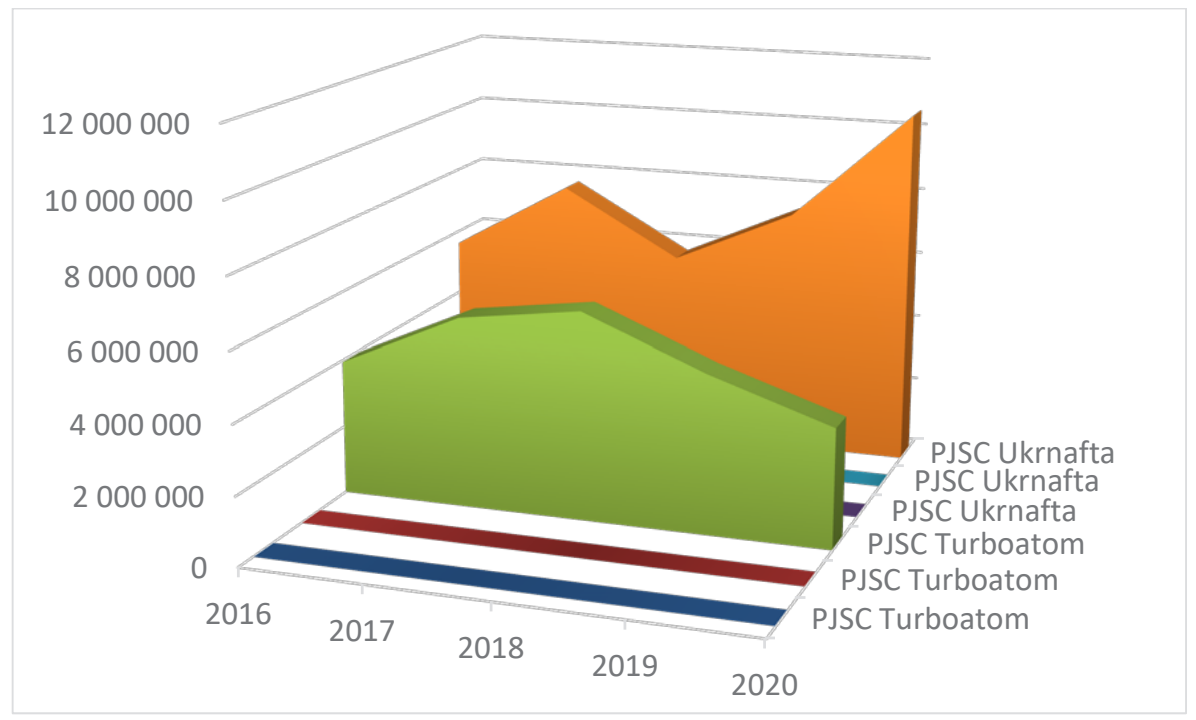

Figure 3. Dynamics of changes in the level of capitalization of PJSC "Ukrnafta" and PJSC "Turboatom" in terms of cost, income and market approaches from 2016 to 2020 in millions of UAH 
average level of correlation of indicators of capitalization, which is evidence of the need for applications of these approaches in the complex.

Based on the above, a conclusion is made about the feasibility of applying a comprehensive cost approach to estimating the capitalization of the enterprise, which is based on the procedure of integration of private estimates of its value. A comprehensive approach to assessing the value of the enterprise based on a combination of cost (property), income and market methods makes it possible to exclude a one-sided evaluation and practically assess the market capitalization of the enterprise and obtain a reliable source of information for its forecasting. In the proposed approach, the sequence of capitalization assessment of the enterprise is represented by the following stages:

1. Formation of information based on the indicators of corporate integrated and financial reporting, taking into account the evaluation priorities and its inherent limitations.

2. Determining the quality criterion for assessing the capitalization of the

enterprise on the basis of the integrated error of the evaluation results by different methods (Kostyrko, 2012) is presented in the form of functional dependence $(I b)$ :

$$
I b=a_{1}\left(\beta_{1}\left(\delta_{m}\right)^{2}+\beta_{2}\left(\delta_{d}\right)^{2}+\beta_{3}\left(\delta_{m}\right)^{2}\left(\delta_{d}\right)^{2}\right)+a_{2}\left(\delta_{m}\right)^{2} \rightarrow \min ,(1)
$$

where $I b$ - functional dependence value of the enterprise;

$\alpha_{1}, \alpha_{2}, \beta_{1}, \beta_{2}, \beta_{3}-$ significance coefficient $\left(\alpha_{1}+\alpha_{2}=1\right.$; $\left.\beta_{1}+\beta_{2}+\beta_{3}=1\right)$;

$\delta_{m}, \delta_{d}$-deviation from the actual value of the enterprise, calculated on the basis of property, income and market approaches.

Comprehensive assessment of the capitalization of the enterprise is carried out on the basis of the cost approach by different methods through the use of weights:

$$
\widetilde{V_{m}}=w c_{c} V_{c}+w c_{i} V+w c_{m} V_{m}
$$

where $w c_{c}, w c_{i}, w c_{m}$ weight coefficients $(w c)$ of value calculated according to cost $(c)$, income $(i)$ and market approaches $(m)$ depending on priorities;
$V_{c}, V_{i}, V_{m}$ - the enterprise value $(V)$ is calculated on the basis of cost (c), income $(i)$ and market approaches $(m)$.

Calculation of a comprehensive assessment of the capitalization of PJSC "Ukrnafta" (Table 2).

3. Comprehensive assessment of the capitalization of the enterprise taking into account the coefficient of quality of assessment by different methods:

$$
C E_{e c}=B_{p} * C_{q} \text {, }
$$

where $C E_{e c}$ - is the complex estimation of enterprise capitalization $\left(C E_{e c}\right), C_{q}$ - evaluation quality coefficient $\left(C_{q}\right)$.

The presented calculations of PJSC "Ukrnafta" capitalization indicate the greatest differences between the value indicators calculated in accordance with the income and market approaches.

The market value of the enterprise according to the market approach is too high, so a comprehensive approach based on the procedure of integrating private estimates of its value is the most effective approach to estimating the company's capitalization.

The use of the proposed approach to the assessment of enterprise capitalization makes it possible to objectively determine the tendencies of its change for further consideration when forecasting the market value.

Fluctuations in the dynamics of the level of capitalization of PJSC "Ukrnafta" indicate the need to increase its level at the expense of the internal value potential. The main directions of increasing the level of capitalization are the introduction of financial methods to increase the capitalization of enterprises, the stimulation of innovative development, the introduction of innovative methods of financial management. Of particular importance in the context of sustainable development is intellectual capital, which is the key to the intensive development of the enterprise and the growth of its market value. This is confirmed by international and European standards, which provide for the assessment of both the enterprise as a whole, and its individual parts.

Table 2

The results of the comprehensive assessment of the capitalization of PJSC «Ukrnafta» for 2016-2020, million UAH

\begin{tabular}{|l|c|c|c|c|c|}
\hline \multicolumn{1}{|c|}{ Approach to evaluation } & 2016 & 2017 & 2018 & 2019 & 2020 \\
\hline Cost & 3090 & 728 & 6919 & 6290 & 9752 \\
\hline Profitable & $(-1073)$ & 3 & 1146 & $(-637)$ & 1341 \\
\hline Market & 560993 & 765326 & 569399 & 732084 & 1057455 \\
\hline Comprehensive cost assessment & 4020 & 649 & 3816 & 5301 & 1140 \\
\hline Deviations from the comprehensive assessment & \multicolumn{5}{|c|}{} \\
\hline Cost & 930 & -79 & -3102 & -989 & -8611 \\
\hline Profitable & 5093 & 646 & 2670 & 5938 & $-201-$ \\
\hline Market & -556972 & -7646762 & -56558 & -726782 & -1056314 \\
\hline
\end{tabular}




\section{Conclusion}

Actualization of the issue of assessing the capitalization level of domestic enterprises is related to the wide recognition of this process in international practice through the possibility of characterizing the competitiveness, profitability and investment attractiveness of the economic entity.

In modern practice, the following mechanisms are used to determine the level of enterprise capitalization: exchange mechanism, OTC or over-the-counter mechanism, valuation mechanism and research mechanism. The exchange mechanism is based on the actions of speculators who buy and sell shares traded on the exchange. The OTC mechanism is based on agreements to buy and sell shares of companies that are not traded on the stock market and have no liquidity. The evaluation and research mechanisms calculate the potential capitalization ratio of the company, which can be realized in the case of the sale of the enterprise or part of it. The assessment mechanism is implemented through such approaches: the cost approach (property), the income approach and the market approach - which are based on value-added factors. It has been substantiated that for a more objective and complete assessment of enterprise's capitalization it is appropriate to use the evaluation mechanism, which is based on the use of a costs-oriented approach and takes into account the factors of evaluation quality. It has been proved that the market value is an indicator of capitalization. The comprehensive assessment of enterprise capitalization is based on the use of an integral index, which takes into account the quality of assessment by different methods.

As part of the study of market value dynamics of corporate enterprises, it is important to compare capitalization with changes in internal and external factors affecting the potential for increasing capitalization.

The developed model of the complex assessment of the capitalization of corporate enterprises is based on the cost-based approach and the integration of private indicators of value calculated by different methods, taking into account the quality factors of assessment. The results of capitalization assessment allow forming objective information for making managerial decisions concerning the choice of capitalization increase sources and forecasting the profitability of invested capital.

\section{References:}

Balitska, V., \& Pyskun, L. (2020). Diagnostics of capitalization of economic agents of Ukraine based on assets and equity funds. Investytsii: praktyka ta dosvid, 24, 26-33.

Blank, I. (2004). Financial management. Kyiv: Elga, 665 p.

Buleev, I., \& Bryukhovetskaya, N. (2011). Capitalization of enterprises: theory and practice. Donetsk: DonUEP, $328 \mathrm{p}$.

Davydenko, N. (2016). Conceptual approaches to capitalization of enterprises. Economic Journal of the Lesia Ukrainka East European National University, 1, 62-67.

Gritsenko, A. (2009). Capitalization and socialization of the economy in retrospect and perspective. Methodology, theory and practice of sociological analysis of modern society, 15, 191-195.

Kostyrko, L. (2012). Financial mechanism of sustainable development of enterprises: strategic guidelines, support systems, adaptation. Lugansk: Knowledge Publishing House, 474 p.

Kozoriz, M. (2007). The role and functions of capitalization in ensuring the economic development of economic entities. Regional economy, 2, 42-48.

Kryvovyazyuk, I., Pushkarchuk, Yu., \& Volynchuk, V. (2017). Capitalization as the basis for dynamic development of enterprises. Economic Forum, 1, 135-144.

Lishchikova, Yu., Nikulina, Yu., Orlova, A., \& Chistnikova, I. (2015). Capitalization assessment as a tool for managing the economic development of the region. Mediterranean Social Science Journal, 6 (3 S5), 93.

Melnyk, L. (2009). Concretization of the concepts of capitalization of the enterprise. Visnyk of Khmelnytsky National University, 4(3), 24-29.

Mocherny, S. (2000). Economic Encyclopedia: in 3 volumes. Kyiv: Publishing Center Academy, 864 p.

Pronko, L., Kolesnik, T., \& Samborskaya, O. (2021). The essence and concept of the capitalization of companies, its types and methods of assessment. European Journal of Sustainable Development, 10(1), 551.

Rosenberg, J. (1997). Investments: Glossary. Moscow: INFRA-M, 472 p.

Sabadireva, A. (2017). Capitalization of enterprise potential. Mechanism of economic regulation, 1, 48-59.

Shevchenko, N. (2008). Features of the study of the essence of capitalization of industrial enterprises. Regionalna ekonomika, 3, 175-181.

Zaitseva, L. (2021). O Influence of free-float on market capitalization of companies. Young scientist, 3, 100-106. 